\title{
HEALTH RISK OF PUPILS FORMED BY CLASSROOMS' AIR POLLUTION
}

\author{
A.N. Gankin, T.D. Gritsenko, S.M. Sokolov, T.N. Pronina
}

State institution "Republican Scientific Practical Center of Hygiene", 8, Akademicheskaya St., Minsk, 220012, Republic of Belarus

\begin{abstract}
The results of health risk assessment of pupils performed on the basis of the classrooms' diffusion air sampling in the establishments of the general education and measurements of the pollutants' concentrations in the air in real time are presented. It was found that classrooms' air pollution is characterized by multicomponent and significant variability. The ajor contribution to the value of total cancer risk in the classrooms' air is made by formaldehyde. The total cancer risk by inhalation routes of benzene, ethylbenzene and formaldehyde administration is higher in the classrooms air compared with ambient air. Hazard index ranges from 1.0 and below under chronic inhalation of classrooms' air contaminants. Combined exposure to chemicals polluting the classrooms' air environment, in concentrations not exceeding the established limits, creates an increased risk of respiratory diseases (hazard index value is to 1.4). Diffusion air sampling allows to provide an assessment of classrooms" air quality, to be the basis for risk assessment, plan and evaluate the effectiveness of "targeted" preventive measures.
\end{abstract}

Key words: classroom air, diffusion sampling, risk assessment.

Scientific data show that chemical air pollution is an important factor affecting respiratory organs, cardiovascular system, and endocrine system. According to the WHO, the air environment in residential units can have a negative effect on human health. This factor is very important since one spends $70 \%$ of the time in non-industrial facilities; here, the air quality ranges between the quality in the residential areas air and the work areas [3,5]. Recent studies have shown that the quality of indoor air in educational facilities can be an important factor causing health disorders in children and teenagers [9, 10]. Taking into account the amount of potential chemical pollution sources in educational facilities, the qualitative composition of pollution, fluctuations in the concentrations of pollutants as well as their combined health effects, preventative measures aimed at mitigating the negative inhalation effects of pollutants and management decisions should be based on the results of risk assessment.

Control and monitoring of indoor air pollution, in particular, classroom air in educational facilities, require appropriate methods that reflect direct exposure limit. Diffusion and passive air sample collection are among today's long-range and effective methods $[4,6]$. The advantages of diffusion sample collection method is the compact size of the sample-collecting device, no need

(C) Gankin A.N., Gritsenko T.D., Sokolov S.M., Pronina T.N., 2014

Gankin Aleksandr Nikolaevich - junior research associate of the Laboratory of Integrated Risk Assessment of Environmental Factors (e-mail: gankinan@gmail.com, tel.: 8 (017) 292-47-00, fax: 8 (017) 284-03-45).

Gritsenko Tatiana Dmitrievna - CBS, leading research associate of the Laboratory of Integrated Risk Assessment of Environmental Factors (e-mail: gritsenkotd@rambler.ru, tel.: 8 (017) 294-13-79).

Sokolov Sergey Mikhailovich - MD, Professor, Honored Scientist of the Republic of Belarus, chief research associate of the Laboratory of Integrated Risk Assessment of Environmental Factors (e-mail: rspch@rspch.by, tel.: 8 (017) 294-13-79).

Pronina Tatiana Nikolaevna - CM, Head of the Laboratory of Hygiene of Children and Adolescents (e-mail: pro_tanya@mail.ru, tel.: 8 (017) 292-82-49). 
for constant electrical supply or power-generating units, large area coverage, high economic effect, noiseless operation and no need for specially trained staff. Sample collection is not affected by peak pollution fluctuations, and the results reflect average pollution levels for the sampling period.

The purpose of this research is to implement hygienic health assessment of students under combined chemical exposure in indoor classroom air using diffusion sampling method.

Materials and methods. The study is based on cluster stratified sampling conducted in twenty elementary school classrooms in five Minsk secondary educational facilities (hereinafter - EF). The choice of priority pollutants affecting the classroom environment is based on the international guidelines $[1,2,7,8]$. We collected the samples of benzene, toluene, ethylbenzene, xylene, formaldehyde, nitrogen oxide (IV) (nitrogen dioxide), and solid particles $<10 \mu \mathrm{m}\left(\mathrm{PM}_{10}\right)$.

We used the data collected by diffusion sampling and real-time pollution data to calculate cancer and non-cancer risks. The study relies on the data collected by diffusion sample collecting devices (Radiello@, Italy). Activated carbon served as absorbent - for BTEX compounds benzene, toluene, ethylbenzene, and xylene isomer mixture; 2,4-dinitrophenylhydrazine - for formaldehyde; trietanolamine - for nitrogen oxide. The sample collection period totaled 6 hours. The chemical analysis of samples was conducted at a reference laboratory using gas chromatography-mass spectrometry and spectral photometry.

The level of $\mathrm{PM}_{10}$ in indoor classroom air was measured on a real-time basis with the use of HAZ-DUST EPAM-5000 (SKC Inc., USA) which utilizes the principle of near-forward light scattering of an infrared radiation to immediately and consistently measure in $\mathrm{mg} / \mathrm{m} 3$ the concentration of airborne dust particles. Besides the air samples, we also collected the data on the sanitary and hygienic condition of the classroom environment.

Risks to student health were assessed in a staged manner. At the first stage, we summarized and analyzed the information about the classroom chemical pollutants that have a carcinogenic effect. Then we calculated individual carcinogenic risk $(C R)$ for benzene, ethylbenzene and formaldehyde as well as total carcinogenic risk (TCRa) for the inhalation exposure.

The noncancer risk was measured with the use of hazard quotient $(H Q)$ when analyzing individual pollutants, and hazard index $(H I)$ when analyzing combined chemical exposure with the account for critical organs (systems) affected by the chemicals under study.

Data analysis was conducted using Statistica software (StatSoft Inc., version 6.0); we tested the data distribution with the Shapiro-Wilk test, and measured the central tendency and dispersion (median, interquartile range). The Kruskal-Wallis test $(H)$ and Mann-Whitney test $(Z)$ 
was used to compare the groups. Correlation was calculated with the use of the Spearman correlation coefficient $₫$. The level of statistical significance was $<0,05$.

Results and discussion. The analysis of the sanitary and hygienic conditions of indoor classroom environment revealed that the facilities were built mainly in the second half of the $20^{\text {th }}$ centuries; the materials used were brick and concrete. The use of standard design projects during the construction of educational facilities determined the use of central heating and free-activated air ventilation systems (with venting passages) and partially automated ventilation system (in the chemistry and physics classrooms). Eleven out of 20 classrooms were located on the $3^{\text {rd }}$ floor; 7 - on the $2^{\text {nd }}$ floor; 2 - on the $1^{\text {st }}$ floor. The average classroom area totaled $61 \mathrm{~m}^{2}$, average volume $-183 \mathrm{~m}^{3}$. In 19 classrooms, the floors were covered with polymeric materials (floor-cloth, parquetene), the most common wall finishing material - wallpaper and water paint. In six classrooms, the walls were covered with PVC panels. The last refurbishing (including re-painting of the walls, window frames and replacement of the furniture) took place in 9 classrooms 3 years ago, in 7 classrooms - 1-2 years ago, and in 4 classrooms - less than a year ago. The furniture was used in 9 classrooms for over 10 years, in 11 classrooms - for 2-4 years; the most common furniture material was MDF.

The analysis of collected samples of benzene, toluene, ethylbenzene, xylene, nitrogen dioxide, and $\left(\mathrm{PM}_{10}\right)$ showed that the concentrations did not exceed the hygienic standards (average daily maximum permissible concentration $\mathrm{MPC}_{\mathrm{da}}$ ) for pollution levels in the air of the residential and public recreation areas. We registered the increase of formaldehyde $M P C_{d a}$ level in the air of one educational facility $\left(\mathrm{MPC}_{\mathrm{da}}-12 \mathrm{mcg} / \mathrm{m}^{3}\right)$. After the comparative and correlation analysis of the levels of the indoor air pollutants, the pollutants under study were broken down into two conventional groups: atmospheric air contaminants (nitrogen dioxide, $\mathrm{PM}_{10}$, benzene) and the pollutants emitted by indoor pollution sources (toluene, ethylbenzene, xylene, formaldehyde).

The level of carcinogenic risk in the classroom air from benzene and ethylbenzene exposure is characterized as 'acceptable' (Risk $<1 \mathrm{E}-06$ ), from formaldehyde in 19 classrooms - as 'permissible' (1E-06 < Risk < 1E-04), and in one classroom - as 'standard' (Risk<1E-06). However, the $C R$ values for benzene, ethylbenzene and formaldehyde as well as the $T C R_{\mathrm{a}}$ value vary significantly from facility to facility.

Table 1 shows that the maximum $C R$ value from benzene exposure is registered in the classroom air of EF 2; here, benzene exposure also exceeds the levels in other facilities. The highest $C R$ level associated with ethybenzene exposure was registered in the air of EF 4 characterized by higher exposure to this chemical contaminant. The lowest $C R$ level associated with benzene and ethylbenzene exposure was registered in EF 5; the level of exposure to these 
contaminants was also minimal. The highest $C R$ level associated with formaldehyde exposure was registered in the air of EF1, the lowest - in the air of EF $3(Z=2,3$ при $p<0,05)$. At the same time, the maximum $T C R_{\mathrm{a}}$ value was determined at EF 1 and the minimum - at EF 3 (the difference is statistically significant, $Z=2,3, p<0,05)$. The biggest contributor to the total carcinogenic risk in the air of educational facilities is formaldehyde.

Table 1

Distribution of individual carcinogenic risk (CR) associated with benzene, ethylbenzene, formaldehyde exposure and total carcinogenic risk associated with inhalation exposure $\left(T C R_{a}\right)$ in the air of educational facilities

\begin{tabular}{|c|c|c|c|c|}
\hline \multirow{2}{*}{ Distribution parameters } & \multicolumn{3}{|c|}{$C R$ value $\left(\cdot 10^{-6}\right)$} & \multirow{2}{*}{$T C R_{\mathrm{a}}$ value $\left(\cdot 10^{-6}\right)$} \\
\hline & benzene & ethylbenzene & formaldehyde & \\
\hline \multicolumn{5}{|c|}{ EF 1} \\
\hline Median & 0,498 & 0,0189 & $2,205^{*}$ & $2,73^{*}$ \\
\hline 25 th procentile & 0,462 & 0,017 & 2,025 & 2,512 \\
\hline 75th procentile & 0,5225 & 0,026 & 3,085 & 3,627 \\
\hline \multicolumn{5}{|c|}{ EF 2} \\
\hline Median & 0,5171 & 0,0202 & 2,005 & 2,564 \\
\hline 25th procentile & 0,5056 & 0,0202 & 1,545 & 2,082 \\
\hline 75th procentile & 0,5356 & 0,02271 & 2,735 & 3,282 \\
\hline \multicolumn{5}{|c|}{ EF 3} \\
\hline Median & 0,4163 & 0,018 & $1,195^{*}$ & $1,631^{*}$ \\
\hline 25 th procentile & 0,3794 & 0,018 & 0,95 & 1,385 \\
\hline 75th procentile & 0,452 & 0,01891 & 1,26 & 1,7 \\
\hline \multicolumn{5}{|c|}{ EF 4} \\
\hline Median & 0,3586 & 0,0391 & 2,085 & 2,538 \\
\hline 25 th procentile & 0,3286 & 0,0329 & 1,77 & 2,196 \\
\hline 75th procentile & 0,4048 & 0,0478 & 2,405 & 2,793 \\
\hline \multicolumn{5}{|c|}{ EF 5} \\
\hline Median & 0,2432 & 0,015 & 1,8 & 2,122 \\
\hline 25 th procentile & 0,202 & 0,0114 & 1,5 & 1,866 \\
\hline 75th procentile & 0,347 & 0,0189 & 2,005 & 2,219 \\
\hline
\end{tabular}

Note: $*$ - the values are significantly different $(p<0,05)$.

The values of individual carcinogenic risk (CR) associated with the benzene, ethylbenzene, and formaldehyde exposure differ depending on the location of the educational facility. For example, CR associated with benzene and ethylbenzene exposure has the highest value in the air of EF 2 location (values CR 6,97E-07 and 2,77E-08 respectively), and the lowest - in the air of EF 4 location (values CR 1,7E-07 and 7,6E-09 respectively). CR associated with formaldehyde exposure has the highest value in the air of EF 1 location $(8,17 \mathrm{E}-07)$, and the lowest - in the air of EF 3 location (3,37E-07). At the same time, the total carcinogenic risk associated with combined inhalation exposure to chemicals with carcinogenic activity has the highest value in the air of EF 3 location $(1,4 \mathrm{E}-06)$, and the lowest value - in the air of EF 5 location $(6,4 \mathrm{E}-07)$ (Table 2).

Table 2 shows that individual carcinogenic risk associated with benzene and ethylbenzene exposure is significantly higher as compared EF 2. Moreover, individual carcinogenic risk associated 
with benzene and ethylbenzene exposure is significantly higher in the air of EF 4 as compared to atmospheric air. The value of individual carcinogenic risk from formaldehyde exposure in all the studied cases is significantly higher in the air of the analyzed educational facilities as compared to the atmospheric air in the area of their location.

Table 2

The values of individual carcinogenic risk (CR) and total carcinogenic risk associated with inhalation exposure (TCRa) to benzene, ethylbenzene and formaldehyde in the air of educational facilities and the atmospheric air in the area of their location

\begin{tabular}{|c|c|c|c|c|c|c|c|c|}
\hline \multirow{3}{*}{$\begin{array}{c}\text { Air } \\
\text { sampling } \\
\text { point }\end{array}$} & \multicolumn{6}{|c|}{$C R$ values } & \multicolumn{2}{|c|}{$T C R_{\mathrm{a}}$ values } \\
\hline & \multicolumn{2}{|c|}{ Benzene } & \multicolumn{2}{|c|}{ Ethylbenzene } & \multicolumn{2}{|c|}{ Formaldehyde } & \multirow[b]{2}{*}{$\begin{array}{l}\text { Air in the } \\
\text { educational } \\
\text { facilities }\end{array}$} & \multirow[b]{2}{*}{$\begin{array}{c}\text { Atmospheric } \\
\text { air }\end{array}$} \\
\hline & $\begin{array}{l}\text { Air in the } \\
\text { educational } \\
\text { facilities }\end{array}$ & $\begin{array}{c}\text { Atmospheric } \\
\text { air }\end{array}$ & $\begin{array}{l}\text { Air in the } \\
\text { educational } \\
\text { facilities }\end{array}$ & $\begin{array}{l}\text { Atmospheric } \\
\text { air }\end{array}$ & $\begin{array}{l}\text { Air in the } \\
\text { educational } \\
\text { facilities }\end{array}$ & $\begin{array}{l}\text { Atmospheric } \\
\text { air }\end{array}$ & & \\
\hline EF 1 & $4,9 \mathrm{E}-7$ & $5,1 \mathrm{E}-7$ & $1,9 \mathrm{E}-8$ & $1,8 \mathrm{E}-8$ & $2,2 \mathrm{E}-6^{*}$ & $8,1 \mathrm{E}-7^{*}$ & $2,7 \mathrm{E}-6^{*}$ & $1,3 \mathrm{E}-6^{*}$ \\
\hline EF 2 & $5,2 \mathrm{E}-7 *$ & $6,9 \mathrm{E}-7 *$ & $2,0 \mathrm{E}-8^{*}$ & $2,8 \mathrm{E}-8^{*}$ & $2,0 \mathrm{E}-6^{*}$ & $7,3 \mathrm{E}-7 *$ & $2,6 \mathrm{E}-6^{*}$ & $1,4 \mathrm{E}-6 *$ \\
\hline EF 3 & $4,2 \mathrm{E}-7$ & $4,5 \mathrm{E}-7$ & $1,8 \mathrm{E}-8$ & $1,8 \mathrm{E}-8$ & $1,2 \mathrm{E}-6^{*}$ & $3,3 \mathrm{E}-7^{*}$ & $1,6 \mathrm{E}-6^{*}$ & $7,8 \mathrm{E}-7 *$ \\
\hline EF 4 & $3,6 \mathrm{E}-7 *$ & $1,6 \mathrm{E}-7^{*}$ & $3,9 \mathrm{E}-8^{*}$ & $7,6 \mathrm{E}-9 *$ & $2,1 \mathrm{E}-6^{*}$ & $5,7 \mathrm{E}-7 *$ & $2,5 \mathrm{E}-6^{*}$ & $7,6 \mathrm{E}-7 *$ \\
\hline EF 5 & $2,4 \mathrm{E}-7$ & $2,2 \mathrm{E}-7$ & $1,5 \mathrm{E}-8$ & $1,0 \mathrm{E}-8$ & $1,8 \mathrm{E}-6^{*}$ & $4,1 \mathrm{E}-7^{*}$ & $2, \mathrm{E}-6^{*}$ & $6,4 \mathrm{E}-7 *$ \\
\hline
\end{tabular}

Note: $*$ - the difference between the compared groups is statistically significant at $p<0,05$ (Mann-Whitney test).

The calculation and analysis of the hazard indexes under chronic inhalation exposure to the air contaminants at the educational facilities showed that the hazard quotients of all the chemicals under study stood at 1.0 and higher; this means that the exposure risk level is considered 'acceptable (Table 3).

The calculation of the hazard indexes associated with combined chemical exposure at the educational facilities was conducted with the account for the critical organs and systems including the respiratory system, circulatory system, hemic system (blood and blood-making organ related diseases), central nervous system, immune system, visual apparatus (eye and appendages of the eye) as well as endocrine systems.

When comparing the hazard indexes associated with the development of respiratory diseases under combined chemical exposure at the educational facilities of five educational institutions, no statistically significant differences were registered between the hazard indexes (Kruskal-Wallis criterion $\mathrm{H}=7,44$ at $\mathrm{p}=0,1143$ ). It is noteworthy however that the hazard index classified as average was registered in 3 out of 5 educational institutions under study ( 8 educational facilities) (Table 4 ).

We determined the following fluctuations of the hazard index values: $\mathrm{HI}$ associated with the development of respiratory diseases - from 0,69 to 1,4 (median - 0,95); HI associated with the development of circulatory diseases - from 0,22 to 0,68 (median - 0,44); HI associated with the development of blood and blood-making organs related diseases - from 0,08 to 0,24 (median - 0,16) HI associated with the development of nervous system diseases - from 0,05 to 0,22 (median - 0,1); HI associated with the immune system diseases - from 0,07 to 0,87 (median - 0,44); HI associated 
with the development of visual apparatus diseases (eye and appendages of the eye) - from 0,16 to $0,85$ (median - 0,4$)$; HI associated with the development of endocrine system diseases - from 0,05 to $0,32($ median $-0,12)$.

Based on the results of the calculation and analysis of the hazard indexes under chronic inhalation exposure to the air contaminants at the educational facilities, statistically significant differences were determined for the circulatory system $(H=14,96$ at $p=0,0048)$, nervous system $(\mathrm{H}=9,76$ at $\mathrm{p}=0,0447)$, immune system $(\mathrm{H}=11,99$ at $\mathrm{p}=0,0175)$, blood and blood-making organs $(H=14,6$ at $p=0,0056)$, endocrine system $(H=12,19$ at $p=0,0160)$, visual apparatus $(H=10,92$ at $\mathrm{p}=0,0275)$.

Table 3

The value of hazard quotient (HZ) under chronic inhalation exposure to air chemicals at the educational facilities

\begin{tabular}{|c|c|c|c|c|c|c|c|}
\hline \multirow{2}{*}{ Classroom } & \multicolumn{9}{|c|}{$H Q$ value } \\
\cline { 2 - 8 } & Benzene & Toluene & Ethylbenzene & Xylene & Formaldehyde & Nitrogen dioxide & PM $_{10}$ \\
\hline 1 & 0,055 & 0,01 & 0,121 & 0,03 & 0,82 & 0,073 & 0,468 \\
\hline 2 & 0,057 & 0,01 & 0,106 & 0,03 & 0,47 & 0,081 & 0,408 \\
\hline 3 & 0,05 & 0,01 & 0,106 & 0,03 & 0,45 & 0,058 & 0,362 \\
\hline 4 & 0,05 & 0,012 & 0,196 & 0,102 & 0,40 & 0,091 & 0,483 \\
\hline 5 & 0,05 & 0,01 & 0,121 & 0,04 & 0,63 & 0,103 & 0,393 \\
\hline 6 & 0,05 & 0,011 & 0,121 & 0,035 & 0,32 & 0,115 & 0,347 \\
\hline 7 & 0,06 & 0,012 & 0,151 & 0,05 & 0,51 & 0,12 & 0,559 \\
\hline 8 & 0,06 & 0,011 & 0,121 & 0,036 & 0,33 & 0,119 & 0,468 \\
\hline 9 & 0,04 & 0,02 & 0,106 & 0,03 & 0,26 & 0,075 & 0,393 \\
\hline 10 & 0,04 & 0,013 & 0,121 & 0,035 & 0,24 & 0,073 & 0,6 \\
\hline 11 & 0,04 & 0,011 & 0,106 & 0,03 & 0,16 & 0,08 & 0,529 \\
\hline 12 & 0,04 & 0,013 & 0,106 & 0,035 & 0,26 & 0,073 & 0,63 \\
\hline 13 & 0,03 & 0,016 & 0,181 & 0,06 & 0,53 & 0,039 & 0,317 \\
\hline 14 & 0,04 & 0,024 & 0,211 & 0,07 & 0,34 & 0,029 & 0,257 \\
\hline 15 & 0,04 & 0,03 & 0,257 & 0,09 & 0,47 & 0,033 & 0,544 \\
\hline 16 & 0,05 & 0,03 & 0,317 & 0,12 & 0,40 & 0,022 & 0,574 \\
\hline 17 & 0,02 & 0,01 & 0,045 & 0,018 & 0,42 & 0,06 & 0,3 \\
\hline 18 & 0,03 & 0,02 & 0,091 & 0,026 & 0,29 & 0,039 & 0,317 \\
\hline 19 & 0,02 & 0,01 & 0,091 & 0,027 & 0,42 & 0,035 & 0,196 \\
\hline 20 & 0,05 & 0,13 & 0,136 & 0,042 & 0,34 & 0,08 & 0,347 \\
\hline
\end{tabular}

Table 4

Hazard indexes of disease risks (with the account for critical organs and systems) under combined exposure to air chemicals at educational facilities

\begin{tabular}{|c|c|c|c|c|c|c|c|}
\hline \multirow{2}{*}{ Classroom } & \multicolumn{9}{|c|}{ HI value } \\
\cline { 2 - 8 } & $\begin{array}{c}\text { Respiratory } \\
\text { organs }\end{array}$ & $\begin{array}{c}\text { Circulatory } \\
\text { system }\end{array}$ & $\begin{array}{c}\text { Blood and } \\
\text { blood-making } \\
\text { organs }\end{array}$ & $\begin{array}{c}\text { Nervous } \\
\text { system }\end{array}$ & $\begin{array}{c}\text { Immune } \\
\text { system }\end{array}$ & $\begin{array}{c}\text { Eye apparatus (eye and } \\
\text { appendages of the eye) }\end{array}$ & $\begin{array}{c}\text { Endocrine } \\
\text { system }\end{array}$ \\
\hline 1 & 1,4 & 0,52 & 0,18 & 0,1 & 0,87 & 0,82 & 0,12 \\
\hline 2 & 1,01 & 0,46 & 0,2 & 0,1 & 0,53 & 0,47 & 0,11 \\
\hline 3 & 0,91 & 0,41 & 0,16 & 0,09 & 0,5 & 0,45 & 0,11 \\
\hline 4 & 1,09 & 0,53 & 0,19 & 0,16 & 0,45 & 0,4 & 0,2 \\
\hline 5 & 0,83 & 0,4 & 0,22 & 0,1 & 0,37 & 0,32 & 0,12 \\
\hline 6 & 1,18 & 0,45 & 0,21 & 0,1 & 0,68 & 0,63 & 0,12 \\
\hline 7 & 1,09 & 0,52 & 0,23 & 0,1 & 0,38 & 0,33 & 0,12 \\
\hline
\end{tabular}




\begin{tabular}{|c|c|c|c|c|c|c|c|}
\hline 8 & 1,25 & 0,32 & 0,24 & 0,12 & 0,57 & 0,51 & 0,15 \\
\hline 9 & 0,78 & 0,43 & 0,16 & 0,09 & 0,31 & 0,26 & 0,11 \\
\hline 10 & 1,01 & 0,68 & 0,15 & 0,09 & 0,3 & 0,26 & 0,12 \\
\hline 11 & 0,81 & 0,57 & 0,16 & 0,09 & 0,2 & 0,16 & 0,11 \\
\hline 12 & 0,96 & 0,65 & 0,16 & 0,09 & 0,07 & 0,27 & 0,11 \\
\hline 13 & 0,81 & 0,35 & 0,11 & 0,11 & 0,56 & 0,53 & 0,18 \\
\hline 14 & 0,69 & 0,29 & 0,1 & 0,13 & 0,38 & 0,34 & 0,21 \\
\hline 15 & 0,69 & 0,58 & 0,11 & 0,16 & 0,52 & 0,47 & 0,26 \\
\hline 16 & 0,93 & 0,62 & 0,11 & 0,2 & 0,44 & 0,4 & 0,32 \\
\hline 17 & 0,96 & 0,32 & 0,1 & 0,05 & 0,44 & 0,42 & 0,05 \\
\hline 18 & 0,73 & 0,35 & 0,09 & 0,07 & 0,32 & 0,29 & 0,09 \\
\hline 19 & 1,15 & 0,22 & 0,08 & 0,06 & 0,44 & 0,42 & 0,09 \\
\hline 20 & 0,83 & 0,39 & 0,17 & 0,22 & 0,38 & 0,34 & 0,14 \\
\hline
\end{tabular}

Additionally, when analyzing the data with the account for the conditional groups of pollutants (Table 5), it was determined that the biggest contributors to the value of hazard index of respiratory disease development are the chemicals referring to the group of pollutants emitted by indoor sources (solvents and formaldehyde): EF 1, EF 4, EF 5 - 53,9; 54,7; 55,8 \% respectively, while at EF 3 and EF 2 - contaminants from the atmospheric air (69 and 52,8 \% respectively).

Table 5 shows that of the two conditional groups of chemical air pollutants registered at the educational facilities under study, the pollutants in the atmospheric air present up to $90 \%$ of the value of the hazard index related to the development of various circulatory system diseases. The atmospheric air pollutants also affect the hazard index related to the blood and blood-forming organs diseases (up to 67\%).

When comparing the hazard indexes for respiratory diseases calculated for the indoor classroom environment at the educational facilities (separately - for the conditional groups of pollutants), we determined statistically significant differences in the values of the hazard indexes under chronic inhalation exposure to chemicals produced by furniture and finishing materials (Kruskal-Wallis criterion $\mathrm{H}=11,5$ at $\mathrm{p}<0,05$ ).

On the basis of correlation analysis, we determined a positive statistically significant relationship between the hazard index values (for the respiratory and circulatory system disease development) and the floors of the classroom location $(R=0,48$ at $p<0,05$ and $R=0,69$ at $p<0,05$ respectively). This is likely to be connected with insufficient natural ventilation on upper floors.

Conclusions. The data on the quality of indoor classroom air collected with the help of diffusion method showed that the biggest contributor to the value of the total carcinogenic risk in the air of educational facilities is formaldehyde; at the same time, total carcinogenic risk associated with inhaled benzene, ethylbenzene and formaldehyde is significantly higher in the air of educational facilities as compared to the atmospheric air in the area of the facility location. Combined impact of the chemical pollutants in the air of educational facilities at permissible concentrations contributes to a higher risk of respiratory diseases. Diffusion air sample collection is an affordable method to 
control and monitor the air environment at educational facilities over an extended period of time. The results of such monitoring could serve as a basis for a health risk assessment program to study pollution effects; to develop a special-purpose health prevention program and to evaluat its effectiveness.

Table 5

\section{Contribution to the value of hazard index associated with the diseases of respiratory system, circulatory system, blood and blood-making organs in the conditional groups of the pollutants under study (\%)}

\begin{tabular}{|c|c|c|c|c|c|c|}
\hline \multirow{2}{*}{$\begin{array}{c}\text { Educational } \\
\text { facility }\end{array}$} & \multicolumn{5}{|c|}{ Hazard index } \\
\cline { 2 - 7 } & $\begin{array}{c}\text { Respiratory system } \\
\text { group 1* }\end{array}$ & $\begin{array}{c}\text { Compounds of } \\
\text { group 2** }\end{array}$ & $\begin{array}{c}\text { Compounds of } \\
\text { group 1* }\end{array}$ & $\begin{array}{c}\text { Compounds of } \\
\text { group 2** }\end{array}$ & $\begin{array}{c}\text { Compounds of } \\
\text { group 1* }\end{array}$ & $\begin{array}{c}\text { Compounds of } \\
\text { group 2** }\end{array}$ \\
\hline EF 1 & 53,9 & 46,1 & 10,9 & 89,1 & 40,9 & 59,1 \\
\hline EF 2 & 47,2 & 52,8 & 11,2 & 88,8 & 32,7 & 67,3 \\
\hline EF 3 & 31,0 & 69,0 & 7,0 & 93,0 & 35,12 & 64,9 \\
\hline EF 4 & 55,8 & 44,2 & 10,1 & 89,9 & 35,3 & 64,7 \\
\hline EF 5 & 54,7 & 45,3 & 8,5 & 91,5 & 56,2 & 43,8 \\
\hline
\end{tabular}

Note: * - compounds of group 1 - substances emitted by furniture and indoor finishing materials; ** compounds of group 2 - chemicals in the atmospheric air.

\section{References}

1. Instrumenty dlya monitoringa vypolneniya obyazatel'stv Parmskoi konferentsii: otchet o soveshchanii 25-26 noyabrya 2010 g., Bonn, Germaniya [Tools for monitoring of adherence to the Parma Conference: report of the meeting on 25-26 November 2010, Bonn, Germany]. World Health Organization. Kopengagen, 2011. 37 p.

2. Metody monitoringa kachestva vozdukha $\mathrm{v}$ shkol'nykh pomeshcheniyakh: otchet o soveshchanii 4-5 aprelya 2011, Bonn, Germaniya [Methods for monitoring of air quality in schools: report of the meeting on 4-5 April 2011, Bonn, Germany]. World Health Organization. Kopengagen, $2011.30 \mathrm{p}$.

3. Otsenka issledovanii po izucheniyu dlitel'nogo vozdeistviya zagryazneniya vozdukha na razvitie khronicheskikh boleznei: otchet o soveshchanii Rabochei gruppy [Evaluation of studies on the long-term effects of air pollution on the development of chronic diseases: report of the Working Group]. World Health Organization. Bonn, 2002. 254 p.

4. Poddubnyi V.A., Yushketova N.A. Metod passivnogo otbora prob dlya izmerenii dioksida azota $\mathrm{v}$ atmosfernom vozdukhe [Passive sampling method for the measurement of nitrogen dioxide in the air]. Optika atmosfery i okeana, 2013, no. 9, pp. 759-765.

5. Pol'ka N.S., Lyashenko V.I., Dzhurinskaya S.N., Shkarban E.S. Khimicheskoe zagryaznenie vozdukha pomeshchenii detskikh uchrezhdenii [Chemical contamination of indoor air of childcare institutions]. Gigiena naselenikh mists', 2010, no. 56, pp. 278-281.

6. Yushketova N.A., Poddubnyi V.A. Metod passivnogo otbora prob dlya monitoringa khimicheskogo zagryazneniya atmosfernogo vozdukha. Chast' 2. Prakticheskie aspekty (obzor) [Passive sampling method for monitoring chemical air pollution. Part 2. Practical aspects (review) ]. Ekologicheskie sistemy i pribory, 2007, no. 3, pp. 15-23.

7. Critical Appraisal of the Setting and Implementation of Indoor Exposure Limits in the EU: summary on recommendations and management options. JRC/IHCP/PCE, Ispra, Italy, 2004, p. 27. 
8. Sarigiannis D.A., Karakitsios S.P., Gotti A., Liakos I.L., Katsoyiannis A. Exposure to major volatile organic compounds and carbonyls in European indoor environment and associated health risk. Environmental International, 2011, vol. 37 (4), pp. 743-765.

9. Fiore A.M., Naik V., Spracklen D.V., Steiner A., Unger N., Prather M., Bergmann D., Cameron-Smith P.J., Cionni I., Collins W.J. Global air quality and climate. Chemical Society reviews, 2012, Vol. 41, pp. 6663-6683.

10. Kampa, M., Castanas, E. Human health effects of air pollution. Environmental Pollution, 2008, vol. 151 (2), pp. 362-367. 